\title{
PENGARUH KEBIASAAN BELAJAR AKTIF SISWA TERHADAP PRESTASI BELAJAR DI KELAS VIII MTS. YPPI WONOREJO BELITANG
}

\author{
Istikomah, Karoma, Annisa Astrid \\ Universitas Islam Negeri Raden Fatah Palembang \\ E-mail: qisti6831@gmail.com,karoma1963@gmail.com, annisaastrid_uin@radenfatah.ac.id
}

How to Cite:

Istikomah, Karoma, Astrid. A. (2021). Pengaruh Kebiasaan Belajar Aktif Siswa Terhadap Prestasi Belajar di Kelas VIII MTs. YPPI Wonorejo Belitang. Fitrah: Journal of Islamic Education, 2(1), 25-36.

\section{ARTICLE HISTORY \\ Received : 00-Month-0000 \\ Revised :00-Month-0000 \\ Accepted : 00-Month-0000 \\ Published : 00-Month-0000}

\section{KEYWORDS:}

Active Learning, Learning Achievement, study habits

\begin{abstract}
This study departs from active learning habits that will affect student achievement in MTs schools. YPPI Wonorejo. This study aims to analyze students' active study habits and their effect on student achievement. The method used is quantitative with a descriptive survey approach. The research population is all students grade VIII, totaling 176, of which 100 students are set as samples by using proportionate stratified random sampling technique. Methods of collecting data with questionnaires, unstructured interviews and documentation were analyzed using descriptive statistical analysis, normality test, linearity test, and regression test. The results of the study show that: (1) The level of active learning habits of students is in the good category, this is proven by the mean value of 66.96 , median of 65.50 , mode of 65 , standard deviation of 9.710 . (2) Student learning achievement is also in good category, which is the mean 71.70, median 73.00, mode 80, standard deviation 7.175. (3) There is a significant effect between active study habits on student achievement. It is characterized by a significant linear relationship $(0.114>0.05)$, and the value of $t_{\text {count }}>t_{\text {table }}(3.710>1.987)$.
\end{abstract}

\section{RIWAYAT ARTIKEL}

Diterima : 00-Month-0000 Direvisi : 00-Month-0000 Disetujui : 00-Month-0000

Diterbitkan : 00-Month-0000

\section{KATA KUNCI:}

Belajar Aktif, Prestasi Belajar, kebiasaan belajar

\section{ABSTRAK}

Penelitian ini berangkat dari kebiasaan belajar aktif yang akan mempengaruhi prestasi siswa di sekolah MTs. YPPI Wonorejo. Penelitian ini bertujuan untuk menganalisis kebiasaan belajar aktif siswa dan pengaruhnya terhadap prestasi belajar siswa. Metode yang digunakan ialah kuantitatif dengan pendekatan survey deskriptif. Populasi penelitiannya ialah seluruh siswa kelas VIII yang berjumlah 176, dari jumlah tersebut ditetapkan 100 siswa sebagai sampel dengan menggunakan. teknik proportionate stratified random sampling. Pengumpulan data dengan angket, wawancara dan dokomuntasi, yang dianalisis menggunakan statistik deskriptif, uji normalitas, uji linearitas, dan uji regresi. Hasil penelitian menujukkan: (1) tingkat kebiasaan belajar aktif siswa berada pada kategori baik, hal ini terbukti dengan nilai rata-rata mean 66,96, median 65,50, mode 65, standar deviasi 9,710. (2) Prestasi belajar siswa juga dalam kategori baik yang didapat yaitu mean 71,70, median 73,00, mode 80, standar deviasi 7,175. (3) Terdapat pengaruh yang signifikan antara kebiasaan belajar aktif terhadap prestasi belajar siswa, hal itu ditandai dengan hubungan linear signifikan $(0,114>0,05)$, dan nilai thitung $>t_{\text {tabel }}(3,710>1,987)$. 
PENDAHULUAN

Pendidikan diselenggarakan untuk mengembangkan budaya membaca, menulis, dan berhitung bagi setiap warga negara $(N$. Purwanto, 2014). Keterampilan belajar membaca, menulis, dan berhitung dapat mendorong seseorang untuk ddapat mengembangkan bakat dan minatnya. Oleh karena itu, seseorang yang berpendidikan diharapkan dapat menjadi faktor pendorong dalam memajukan suatu bangsa. Pendidikan tidak lepas dari kegiatan belajar. Perubahan tingkah laku seseorang baik secara fisik, intelegensi, keterampilan, sikap, dan emosi menunjukkan adanya peningkatan potensi seseorang. Peningkatan potensi yang terjadi pada seseorang itu menunjukkan bahwa adanya peningkatan hasil belajar di sekolah. Hasil belajar merupakan kegiatan belajar yang dilakukan siswa dimana selama kegiatan belajar berlangsung akan menghasilkan perubahan tingkah laku (Arikunto et al., 2001). Kebiasaan belajar siswa di Madrasah Tsanawiyah MTs. YPPI Wonorejo Belitang Kabupaten Ogan Komering Ulu Timur. Khususnya siswa kelas VIII menerima pelajaran, membaca buku, dan mengerjakan tugas, belajar dalam waktu yang telah di tentukan.

Cara yang dilakukan siswa dalam belajar berbeda-beda, siswa akan menyadari bagaimana cara belajar yang baik, sehingga siswa tersebut menjadi lebih bertanggungjawab akan kegiatan belajarnya. Keterampilan belajar yang baik akan membentuk kebiasaan belajar yang baik pula. Oleh karena itu, pembentukan kebiasaan belajar perlu dikembangkan. Kebiasaan belajar siswa ini terbentuk di sekolah maupun di luar sekolah. Kegiatan belajar siswa yang dilakukan secara berulang-ulang selama mengikuti proses pembelajaran di sekolah maupun kegiatan belajar yang dilakukan di rumah. (Widayanti, 2013).

Kebiasaan belajar Aktif akan mempengaruhi prestasi belajar siswa di sekoah di MTs. YPPI Wonorejo khususnya, cara kebiasaan belajar yang berbeda akan menjadi suatu cara yang melekat pada diri siswa, sehingga siswa akan melakukannya dengan senang dan tidak ada paksaan. Hal itu menunjukkan belum terbentuknya suatu kebiasaan belajar yang efektif. Pembentukan suatu kebiasaan belajar yang baik dapat dilihat dari aktivitas dan kesiapan belajar siswa pada saat di sekolah. Kegiatan belajar siswa di sekolah seperti antusias siswa dalam mengikuti proses pembelajaran, cara merespon apa yang disampaikan guru, dan sebagainya. Sebelum proses pembelajaran, siswa harus dipersiapkan dahulu oleh guru seperti mengeluarkan buku mata pelajaran yang akan dipelajari. (Pane \& Dasopang, 2017). Beberapa siswa yang tidak membawa buku catatan, menunjukkan bahwa siswa tersebut kurang mempersiapkan diri dalam mengikuti proses pembelajaran. Saat proses pembelajaran, beberapa siswa saja yang aktif, sehingga terlihat mana yang memiliki kesiapan 
dalam belajar dan mana yang tidak. Sementara, kebiasaan menyontek jawaban teman masih sangat membudaya. Sebagian besar siswa mudah lupa dengan materi yang sudah diajarkan.

Sebagai contoh, apabila guru bertanya tentang materi yang sudah diajarkan, siswa cenderung diam dan kurang tanggap dalam menjawab pertanyaan guru. Kemampuan dalam menerima materi pelajaran setiap siswa memang berbedabeda. Sebagian besar siswa hanya mencoba untuk menghafal materi pelajaran saja. Belajar dengan cara menghafal materi pelajaran, menunjukkan apa yang dipelajari hanya disimpan dalam ingatan jangka pendek, sehingga mudah lupa. Kegiatan belajar yang dilakukan siswa berbeda-beda. Ada siswa yang hanya mendengarkan penjelasan guru langsung paham, namun ada juga siswa yang harus membaca ulang materi yang sudah dijelaskan. Guru harus menjelaskan materi pelajaran secara ulang, baru siswa bisa memahami apa yang telah disampaikan oleh guru. Namun, ada beberapa siswa yang rajin merangkum materi yang disampaikan oleh gurunya.

Proses pembelajaran di kelas VIII MTs. YPPI Wonorejo Belitang Kabupaten Ogan Komering Ulu Timur, siswa perlu diberi latihan soal agar pemahaman tentang materi benar-benar dikuasai. Saat guru memberikan soal latihan, terlihat beberapa siswa yang mengerjakan dengan sungguh- sungguh, namun ada pula yang memerlukan bimbingan khusus. Guru harus berkeliling melihat dan mendampingi siswa dalam proses mengerjakan soal latihan tersebut. Berbeda dengan siswa yang tanggap dan belajar secara teratur, siswa tersebut akan bertanggungjawab dengan tugasnya serta mempunyai keinginan yang tinggi untuk mendapatkan nilai yang baik. Banyak siswa yang mendapatkan hasil kurang maksimal karena siswa tersebut kurang memahami cara-cara belajar yang efektif. Siswa yang memiliki kebiasaan belajar yang aktif, maka kemampuan untuk menerima materi pelajaran lebih cepat dan akan terdorong untuk berprestasi lebih baik lagi. Peran guru menjadi sangat penting dalam membina kebiasaan belajar siswa.

Tentu saja kebiasaan belajar aktif ini akan mempengaruhi prestasi belajar siswa. Prestasi ataupun capaian kumulatif terhadap tujuan pembelajaran tidak hanya dipengaruhi oleh kemampuan kognitif semata, akan tetapi juga dipegaruhi oleh kebiasaan yang ada pada diri peserta didik tersebut. Kebiasaan yang dimaksud tentu saja kebiasaan belajar. Kebiasaan belajar aktif ini memang tidak dapat diciptakan sendiri oleh siswa, mereka membutuhkan stimulus dari guru. (Dalimunthe,2021). Namun bagaimana membentuk stimulus tersebut menjadi satu hal yang terbiasa pada diri itu menjadi tanggung jawab diri siswa tersebut. Secara sederhana belajar aktif tentu memicu motivasi 
siswa dalam mencapai tujuan pembelajaran yang telah ditentukan. (Lubis et al., 2019).

Prestasi belajar merupakan bagian dari perbuatan belajar, karena belajar merupakan suatu proses, sedangkan prestasi belajar adalah hasil dari proses pembelajaran tersebut. Bagi seorang siswa belajar merupakan suatu kewajiban. Berhasil atau tidaknya seorang siswa dalam pendidikan tergantung pada proses belajar yang dialami oleh siswa tersebut. Proses pembelajaran yang baik tentu ditandai dengan kebiasaan yang terulang dengan baik, begitu juga dengan sebaliknya. (Manurung, 2021). Kebiasaan belajar baik memang tidak serta merta menghantarkan siswa itu unggul dibandingkan dengan siswa lainnya. Tetapi paling tidak memberikan pengaruh terhadap pencapaian diri sendiri. (Fahmi \& Bitasari, 2021).

Siswa kelas VIII MTs. YPPI Wonorejo memiliki kebiasaan belajar aktif yang berbeda-beda, oleh karena itu perlulah kiranya peneliti melakukan penelitian untuk menganalisis pengaruhnya terhadap prestasi belajar siswa. Penelitian ini memang terbilang bukanlah hal baru, terdapat beberapa penelitian yang memang relevan dengan penelitian ini, yakni pengaruh kemandirian terhadap prestasi belajar (Ningsih \& Nurrahmah, 2016), pengaruh kebiasaan belajar terhadap prestasi belajar siswa (Wijaya \& Saputri, 2019), pengaruh kebiasaan belajar dan lingkungan terhadap hasil belajar siswa (Hidayat, 2017), pengaruh minat terhadap hasil belajar siswa (Siagian, 2015), pengaruh kebiasaan belajar dan kepercayaan diri terhadap hasil belajar siswa (Adriani, 2018). Dari beberapa penelitian tersebut tampak bahwa belum terdapat yang kajian penelitian yang fokusnya pada kebiasaan belajar aktif siswa dan pengaruhya terhadap hasil belajar. Maka berdasarkan uraian di atas, maka penelitian ini difokuskan pada tujuan untuk mengtahui pengaruh kebiasaan belajar aktif siswa terhadap prestasi siswa VIII di Mts. YPPI Wonorejo. Penelitian ini tentu memiliki kontribusi yang tinggi, terutama bagi guru sebagai informasi untuk meningkatkan kebiasan belajar aktif siswa agar tujuan pembelajaran tercapai sehingga akhirnya bermuara pada tercapainya tujuan pembelajaran tersebut.

\section{KAJIAN TEORI}

Belajar adalah perubahan yang relatif permanen dalam perilaku atau potensi perilaku sebagai hasil dari pengalaman atau latihan yang diperkuat. Belajar merupakan akibat adanya interaksi antara stimulus dan respons. Seseorang dianggap telah belajar sesuatu jika dia dapat menunjukkan perubahan perilakunya. (Faizah, 2017)

Secara umum disebut belajar karena telah memiliki ciri khas sebagai berikut (Syarifuddin, 2011):

- Perubahan yang bersifat fungsional.

Perubahan yang terjadi pada aspek 
kepribadian seseorang mempunai dampak pada perubahan selanjutnya. Karena belajar anak dapat membaca, karena belajar pengetahuan bertambah, karena pengetahuannya bertambah akan mempengaruhi sikap dan perilakunya.

- Belajar adalah perbuatan yang sudah mungkin sewaktu terjadinya prioritas. Yang bersangkutan tidak begitu menyadarinya namun demikian paling tidak dia menyadari setelah peristiwa itu berlangsung. Dia menjadi sadar apa yang dialaminya dan apa dampaknya. Kalau orang tua sudah dua kali kehilangan tongkat, maka itu berarti dia tidak belajar dari pengalaman terdahulu.

- Belajar terjadi melalui pengalaman yang bersifat individual. Belajar hanya terjadi apabila dialami sendiri oleh yang bersangkutan, dan tidak dapat digantikan oleh orang lain. Cara memahami dan menerapkan bersifat individualistik, yang pada gilirannya juga akan menimbulkan hasil yang bersifat pribadi.

- Perubahan yang terjadi bersifat menyeluruh dan terintegrasi. Yang berubah bukan bagian-bagian dari diri seseorang, namun yang berubah adalah kepribadiannya. Kepandaian menulis bukan dilokalosasi tempat saja. Terapi menyangkut aspek kepribadian lainnya, dan pengaruhnya akan terdapat pada perubahan perilaku yang bersangkutan.

- Belajar adalah prsoses interaksi. Belajar bukanlah proses penyerapan yang berlangsung tanpa usaha yang aktif dari yang bersangkutan. Apa yang diajarkan guru belum tentu menyebabkan terjadinya perubahan, apabila yang belajar tidak melibatkan diri dalam situasi tersebut. Perubahan akan terjadi kalau yang bersangkutan memberikan reaksi terhadap situasi yang dihadapi.

- Perubahan berlangsung dari yang sederhana ke arah yang lebih kompleks. Seorang anak baru akan dapat melakukan operasi bilangan kalau yang bersangkutan sedang menguasai simbol-simbol yang berkaitan dengan operasi tersebut.

Pada dasarnya belajar merupakan perbuatan seseorang, dalam hal ini perbuatan untuk mencapai tujuan belajar agar kelak memiliki prestasi belajar. Prestasi belajar sendiri diartikan sebagai hasil usaha bekerja atau belajar yang menunjukan ukuran kecakapan yang dicapai dalam bentuk nilai. Sedangkan prestasi belajar hasil usaha belajar yang berupa nilai-nilai sebagai ukuran kecakapan dari usaha belajar yang telah dicapai seseorang, prestasi belajar ditunjukan 
dengan jumlah nilai raport atau test nilai sumatif. (Thaib, 2013).

Kenyataan menunjukkan bahwa prestasi belajar seseorang tidaklah sama, tetapi sangat pariatif/ berbeda. Perbedaan ini dapat disebabkan oleh berbagai faktor, yang secara garis besar dapat dibedakan menjadi dua; (1) Faktor dari dalam diri seseoarang (intrinsic) dan (2) Faktor dari luar seseorang (Extrinsic). Termasuk faktor intrinsik ialah intelegensi, motivasi, Sikap, minat, bakat, konsentrasi. Dan termasuk faktor ekstrinsik ialah keluarga, sekolah, masyarakat. (Syafi'i et al., 2018).

Ada beberapa cara untuk meningkatkan prestasi salah satunya adalah dengan memperhatikan dan mencermati gaya belajar dan kebiasaan belajarnya. Kebiasaan belajar merupakan perilaku belajar yang terbentuk pada diri siswa bersamaan dengan proses belajar yang dilakukan karena siswa mempelajari dan mengamati dari lingkungan sekitarnya, bukan bakat yang sudah dimiliki siswa sejak kecil. Melalui proses belajar yang akan terbentuk kebiasaan belajar siswa secara sadar maupun tidak dan proses tersebut berlangsung secara terus menerus. Proses belajar tersebut dilaksanakan siswa ketika berada di rumah maupun di sekolah. Hal tersebut dilakukan oleh siswa untuk memperoleh hasil belajar yang memuaskan. (D. Purwanto, 2020).
Kebiasaan belajar merupakan tingkah laku yang terbentuk karena dilakukan secara berulang-ulang sepanjang hidup individu dan biasanya mengikuti cara atau pola tertentu, sehingga akan terbentuk sebuah kebiasaan belajar. Jadi, yang dimaksud dengan kebiasaan belajar di sini adalah cara-cara belajar yang paling sering dilakukan oleh siswa dan cara atau kebiasaan belajar dapat terbentuk dari aktifitas belajar, baik secara sengaja ataupun tidak sengaja.(Rahayu, 2015).

Dimensi dari kebiasaan belajar itu terbagi menjadi dua yaitu Delay Avoidan atau bisa disebut juga kesigapan dalam belajar dan Work Methods atau bisa disebut juga metode kerja dalam belajar. Pada dimensi tentang kebiasaan belajar di atas peneliti mengembangkan kedua dimensi tersebut kedalam sub variabel angket dalam penelitian ini, adapun sub variabel tersebut meliputi: Delay Avoidan (kesigapan dalam belajar) dan Work Methods (metode bekerja dalam belajar). (Saputra et al., 2016).

\section{METODE PENELITIAN}

Adapun metode yang digunakan dalam penelitian ini dengan menggunakan metode kuantitatif. Penelitian ini identik dengan statistik, artinya, pengumpulan dan penganalisaan adalah hubungan dengan data nominal (angka). Data statistik yang diperoleh dilapanngan khususnya para responden kemuadian dianalisis menggunakan regresi linier sederhana untuk mengungkapkan seberapa besar pengaruh kebiasaan belajar 
siswa aktif terhadap prestasi belajar siswa kelas VII MT. YPPI Wonorejo.

Subyek penelitian ini adalah siswa, sedangkan faktor pendukungnya adalah guru, kepala sekolah. Sumber data dalam penelitian ini ada dua, yakni primer dan sekunder. Populasi dalam penelitian ini berjumlah sebanyak 176 orang siswa sedangkan yang dijadikan sampel dalam penelitian ini 100 siswa dengan 20 pertanyaan angket.

Pengumpulan data dilakukan dengan penyebaran angket terhadap siswa-siswi sampel penelitian. Langkah-langkah yang dilakukan dalam pengumpulan data, (1) menemui Kepala sekolah MTS. YPPI Wonorejo provinsi Sumatera Selatan; (2) mengkordinasi dengan wakil kepala bidang kurikulum untuk menentukan waktu untuk bertemu dengan siswaa-siswi sampel penelitian; (3) wakil Kepala MTS. YPPI bidang kurikulum memberikan pengantar, pengarah, dan penjelasan kepada siswa-siswi sampel penellitian didalam ruang kelas; (4) peneliti menjelaskan angket yang akan diisi siswa-siswi sampel penelitian; (5) peneliti memohon kepada sampel penelitian untuk mengisi angket di ruang kelas pada jam istirahat dan mengembalikannya pada saat selesai diisi agar tidak mengganggu waktu belajar siswa-siswi sampel peneltian. Cara penggunaan kuesioner yang lebih efektif adalah apabila pengisian jawabannya dapat dilakukan secara berkelompok pada suatu tempat tertentu. Dalam keadaan seperti ini peneliti dapat memberi petunjuk secara langsung bagaimana cara member jawaban tanpa mempengaruhi isi jawaban yang harus diberikan. Disamping itu peniliti juga mempunyai peluang untuk memberi keterangan atas pertanyaan yang belum jelas maksudnya. Dengan demikian pengisian kuesioner secara klasikal memungkinkan peneliti memperoleh kembali kuesioner secara lengkap dalam waktu yang singkat, sedangkan kesalahan-kesalahan teknis dalam menjawab dapat ditekan hingga sekecil mungkin. Menyebarkan kuesioner secara langsung diaggap paling efektif, hal tersebut juga sesuai pendapat Siyoto yang mengungkapkan bahwa penyebaran angket secara langsung akan lebih efektif karena dapat memastikan langsung bahwa angket telah terisi semua oleh koresponden (Siyoto \& Sodik, 2015). Instrumen penelitian yang akan diajukan kepada siswa-siswi pada sampel penelitian.

Teknik analisis terdiri dari dua kata "Teknik" yaitu cara membuat sesuatu, sedangkan analisis merupakan tindakan mengolah data menjadi infomasi yang bermanfaat untuk menjawab masalah penelitian. Analisis data adalah suatu proses pengklasifikasi, pengkategorian, penyusunan, dan elaborasi sehingga data yang terkumpul dapat diberikan makna untuk menjawab masalah penelitian yang telah dirumuskan atau untuk mengcapai tujuan penelitian. Berdasarkan hal tersebut maka teknik analisis 
data dibedakan menjadi dua yaitu teknik analisis data secara kuantitatif dan teknik analisis data kualitatif.

Data yang terkumpul dianalisis dengan analisis pengaruh untuk menguji masing-masing hipotesis. Sebelum analisis jalur digunakan dilakukan analisis deskriptif, pengujian normalitas, linearitas dan regresi. Data kebiasaan belajar siswa aktif dan prestasi belajar yang dianalisis.

\section{HASIL DAN PEMBAHASAN PENELITIAN}

Hasil dan pembahasan akan disajikan berdasarkan urutan tujuan penelitian sebagaimana yang telah dikemukakan pada bagian pendahuluan yakni sebagai berikut:

\section{Kebiasaan Belajar Siswa Aktif di MTs} YPPI. Wonorejo

Kebiasaan belajar siswa aktif merupakan salah salah satu faktor penunjang tercapainya prestasi belajar siswa. Dalam rangka mencapai prestasi belajar yang diharapkan, maka dalam kegiataan belajarnya, siswa hendaknya mempunyai sikap dan cara belajar yang sistematis. Cara belajar yang baik adalah suatu kecakapan yang dimiliki oleh setiap siswa dengan jalan latihan dalam usaha belajarnya sehingga menjadi kebiasaan yang melekat pada diri siswa. Dengan memiliki kebiasaan belajar yang baik maka setiap usaha belajar akan memberikan hasil yang memuaskan, seperti: Siswa yang rajin menunjuk tangan, siswa yang rajin menjawab soal pertanyaan dari guru, siswa yang sering maju kedepan, siswa yang rajin menulis didepan papan tulis, siswa yang cepat menjawab pertanyaan dari guru.

Ilmu yang sedang dituntut dapat dimengerti dan dikuasai dengan sempurna serta ujian-ujian dapat dilalui dengan berhasil sehingga akhirnya dapat meraih prestasi yang optimal. Kebiasaan belajar yang baik itu haruslah dipupuk dan di kembangkan. Demikian pula kebiasaan belajar itu bukan sesuatu yang telah ada. Namun sesuatu yang harus dibentuk. Sedangkan apabila memiliki kebiasaan belajar yang tidak sesuai atau kurang tepat maka akan memperoleh hasil yang tidak optimal sehingga akan mempengaruhi prestasi belajar siswa yang bersangkutan.

Kebiasaan belajar yang tidak sesuai dapat mempersulit siswa dalam memahami dan memperoleh pengetahuan sehingga menghambat kemajuan belajar siswa dan pada akhirnya akan mengalaami kegagalan dalam berprestasi. Dalam kegiatan sehari-hari ditemukan adanya kebiasaan belajar yang kurang baik. Kebiasaan belajar yang kurang baik antara lain berupa, belajar pada akhir semester, belajar tidak teratur, menyiakan kesempatan belajar, bersekolah hanya untuk bergengsi, datang terlambat, dan laki-laki yang bergaya seperti merokok dan sok menggurui teman lain.

Berdasarkan penelitian menunjukkan siswa yang terbiasa aktif seperti dalam hal, 
siswa yang rajin menunjuk tangan, Siswa yang rajin menjawab soal pertanyaan dari guru, siswa yang sering maju kedepan, siswa yang rajin menulis didepan papan tulis, Siswa yang cepat menjawab pertanyaan dari guru.

Selaras dengan temuan di atas, kebiasaan belajar juga dihitung dengan menggunakan statistika dengan penyebaran angket kepada siswa. Berikut ini perhitungan statistika menggunakan SPSS 21 :

Tabel 1. Perhitungan Statistika Kebiasaan Belajar

\begin{tabular}{|c|c|c|c|c|c|}
\hline Skor & Frequency & Percent & $\begin{array}{c}\text { Valid } \\
\text { Percent }\end{array}$ & $\begin{array}{c}\text { Cumulative } \\
\text { Percent }\end{array}$ \\
\hline Valid & 40 & 1 & 1.0 & 1.0 & 1.0 \\
\hline 475 & 4 & 4.0 & 4.0 & 5.0 \\
\hline 48 & 1 & 1.0 & 1.0 & 6.0 \\
\hline 54 & 6 & 6.0 & 6.0 & 12.0 \\
\hline 55 & 2 & 2.0 & 2.0 & 14.0 \\
\hline 58 & 2 & 2.0 & 2.0 & 16.0 \\
\hline 60 & 10 & 10.0 & 10.0 & 26.0 \\
\hline 61 & 2 & 2.0 & 2.0 & 28.0 \\
\hline 63 & 3 & 3.0 & 3.0 & 31.0 \\
\hline 64 & 6 & 6.0 & 6.0 & 37.0 \\
\hline 65 & 13 & 13.0 & 13.0 & 50.0 \\
\hline 66 & 1 & 1.0 & 1.0 & 51.0 \\
\hline 67 & 6 & 6.0 & 6.0 & 57.0 \\
\hline 68 & 1 & 1.0 & 1.0 & 58.0 \\
\hline 69 & 2 & 2.0 & 2.0 & 60.0 \\
\hline 70 & 4 & 4.0 & 4.0 & 64.0 \\
\hline 71 & 1 & 1.0 & 1.0 & 65.0 \\
\hline 72 & 1 & 1.0 & 1.0 & 66.0 \\
\hline 73 & 1 & 1.0 & 1.0 & 67.0 \\
\hline 74 & 2 & 2.0 & 2.0 & 69.0 \\
\hline 75 & 5 & 5.0 & 5.0 & 74.0 \\
\hline 76 & 3 & 3.0 & 3.0 & 77.0 \\
\hline 77 & 4 & 4.0 & 4.0 & 81.0 \\
\hline 78 & 4 & 4.0 & 4.0 & 85.0 \\
\hline 79 & 3 & 3.0 & 3.0 & 88.0 \\
\hline 80 & 12 & 12.0 & 12.0 & 100.0 \\
\hline Total & 100 & 100.0 & 100.0 & \\
\hline
\end{tabular}

Berdasarkan tabel di atas, kebiasaan belajar siswa aktif terkumpul melalui 20 butir pernyataan dengan skor ideal 80, jumlah skor 6696, skor minimum 40, skor maksimum 80 , mean 66,96, median 65,50, mode 65, standar deviasi 9,710. Selisih skor rata-rata, mode, dan median tidak melebihi satu simpangan baku, yang berarti distribusi skor variabel kebiasan belajar siswa aktif cenderung normal, hasil perhitungan statistika dasar, pada lampiran.

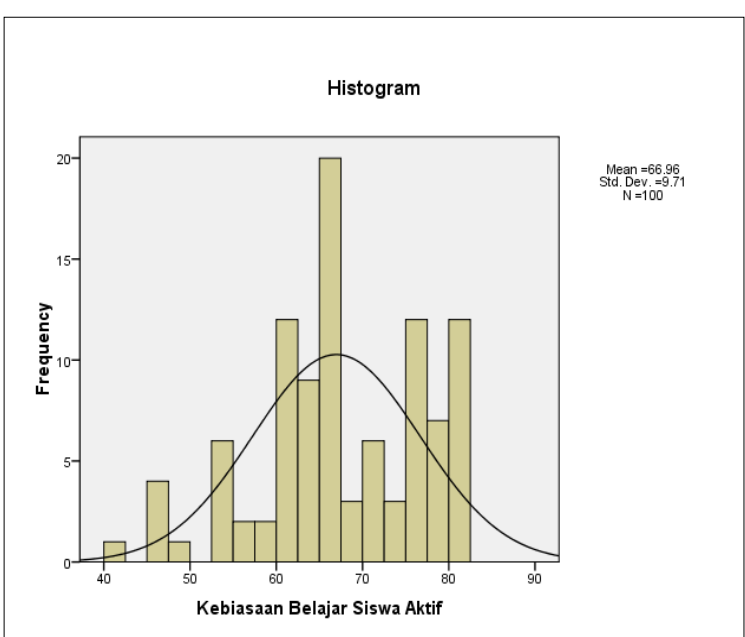

Gambar 1: Histogram Kebiasaan Belajar Siswa

Tabel 1 dan gambar 1 di atas menunjukan $57,5 \%$ skor prestasi belajar berada pada kelas interval skor rata-rata, 75,0 berada diatas skor rata-rata, dan 20,5\% berada dibawah skor rata-rata. Kelihatan sebagian besar skor prestasi belajar berada di atas skor rata-rata.

Data responden angket kebiasaan belajar siswa aktif diperoleh bahwa rata-rata skor kemampuan: manajemen waktu $75,78 \%$, lingkungan belajar 74,76 dan persiapan sebelum proses belajar mengajar 74,93\% hasil data skor tersebut tergolong kuat (baik). 
Fitrah: Journal of Islamic Education

Analisis Prestasi belajar siswa kelas VIII MTs. YPPI Wonorejo

Data prestasi belajar pada penelitian ini di peroleh melalui dokumentasi nilai ratarata ujian semester tahun ajaran 2018/2019 dan di anggap menjadi tolak ukur prestrasi belajar siswa-siswi sampel penelitian. Prestasi belajar dihitung dengan menggunakan statistika menggunakan SPSS 21 :

Tabel 2. Prestasi Belajar Siswa Kelas VIII

\begin{tabular}{|c|c|c|c|c|c|}
\hline \multirow{7}{*}{ Valid } & Skor & Frequency & Percent & $\begin{array}{c}\text { Valid } \\
\text { Percent }\end{array}$ & $\begin{array}{c}\text { Cumulative } \\
\text { Percent }\end{array}$ \\
\cline { 2 - 6 } & 64 & 1 & 1.0 & 1.0 & 1.0 \\
\hline 60 & 11 & 11.0 & 11.0 & 12.0 \\
\hline 61 & 1 & 1.0 & 1.0 & 13.0 \\
\hline 65 & 12 & 12.0 & 12.0 & 25.0 \\
\hline 67 & 7 & 7.0 & 7.0 & 32.0 \\
\hline 68 & 7 & 7.0 & 7.0 & 39.0 \\
\hline 69 & 1 & 1.0 & 1.0 & 40.0 \\
\hline 70 & 8 & 8.0 & 8.0 & 48.0 \\
\hline 73 & 4 & 4.0 & 4.0 & 52.0 \\
\hline 74 & 3 & 3.0 & 3.0 & 55.0 \\
\hline 75 & 10 & 10.0 & 10.0 & 65.0 \\
\hline 76 & 3 & 3.0 & 3.0 & 68.0 \\
\hline 77 & 6 & 6.0 & 6.0 & 74.0 \\
\hline 78 & 4 & 4.0 & 4.0 & 78.0 \\
\hline 80 & 17 & 17.0 & 17.0 & 95.0 \\
\hline 82 & 4 & 4.0 & 4.0 & 99.0 \\
\hline 87 & 1 & 1.0 & 1.0 & 100.0 \\
\hline & Total & 100 & 100.0 & 100.0 & \\
\hline
\end{tabular}

Berdasarkan data di atas, diperoleh jumlah skor 7170 , skor maksimum 87 , skor minimum 54 , mean 71,70 , median 73,00 , mode 80, standar deviasi 7,175 . Selisih skor rata-rata, mode, dan median tidak melebihi satu simpangan baku (standar deviasi) yang bearti distribusi skor variabel prestasi belajar cendrung norma.

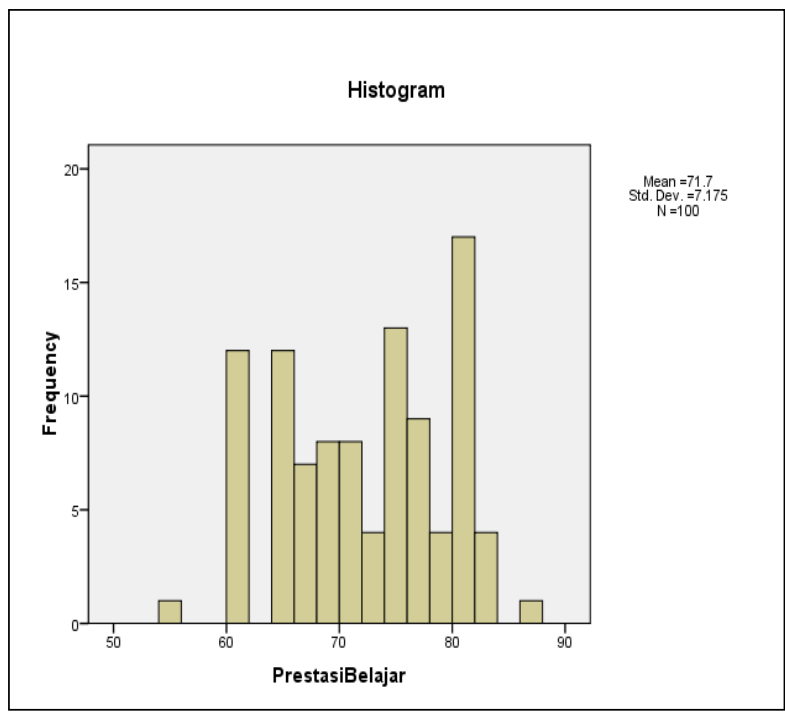

Gambar 2. Histogram Prestasi Belajar

Tabel 2 dan gambar 2 di atas menunjukan $82,5 \%$ skor prestasi belajar berada pada kelas interval skor rata-rata, 85,0 berada diatas skor rata-rata, dan $72,5 \%$ berada dibawah skor rata-rata. Kelihatan sebagian besar skor prestasi belajar berada diatas skor rata-rata.

\section{Pengaruh Kebiasaan Belajar Aktif Siswa terhadap Prestasi Belajar Siswa}

Pengaruh prestasi kebiasaan belajar siswa merupakan salah satu kunci dalam mencapai prestasi belajar. Tentu saja kebiasaan belajar ada kalanya merupakan kebiasaan belajar yang baik dan kebiasaan belajar siswa yang buruk. Setelah menerima pelajaran di kelas, ada baiknya apabila mengulang kembali pelajaran yang di ajarkan oleh guru. Misalnya ada jam kosong maka ada jam kosong tersebut dipergunakan waktu sebaik-baiknya untuk mengulang pelajaran yang baru diajarkan tersebut dikelas. 
Pengaruh kebiasaan belajar terhadap hasil belajar siswa kelas VIII MTs YPPI Wonorejo ditandai dengan adanya hubungan linear secara signifikan $(0,114>0,05)$, dan nilai $t_{\text {hitung }}>t_{\text {tabel }}(3,710>1,987)$. Hal ini menunjukkan bahwa ada pegaruh antara kebiasaan belajar terhadap hasil belajar siswa kelas VIII MTs YPPI Wonorejo.

\section{SIMPULAN}

Berdasarkan hasil dan pembahasan penelitian yang telah dilaksanakan di MTs YPPI Wonorejo, dapat diambil kesimpulan sebagai berikut. (1) Bahwa tingkat capaian kebiasaan belajar siswa aktif berada pada kategori baik, hal ini terbukti dengan nilai rata-rata mean 66,96, median 65,50 , mode 65 , standar deviasi 9,710. (2) Bahwa tingkat capaian prestasi belajar juga dalam kategori baik yang didapat yaitu mean 71,70, median 73,00, mode 80, standar deviasi 7,175. (3) Pengaruh kebiasaan belajar terhadap hasil belajar siswa kelas VIII MTs YPPI Wonorejo ditandai dengan adanya hubungan linear secara signifikan $(0,114>0,05)$, dan nilai $t_{\text {hitung }}$ $>t_{\text {tabel }}(3,710>1,987)$. Hal ini menunjukkan bahwa ada pegaruh antara kebiasaan belajar terhadap hasil belajar siswa kelas VIII MTs YPPI Wonorejo.

\section{DAFTAR PUSTAKA}

Adriani, D. (2018). Pengaruh Percaya Diri, Kebiasaan Belajar dan Motivasi Belajar Terhadap Hasil Belajar Siswa pada Mata Pelajaran Ekonomi. JPEKA: Jurnal Pendidikan Ekonomi, Manajemen dan Keuangan, 2(1), 19-28. http://dx.doi.org/10.26740/jpeka.v2n 1.p19-28
Arikunto, S., Ghofur, A., Pustaka, A.-K., Hajar, I., \& Hawari, D. (2001). Interaksi dan Motivasi Belajar Mengajar. PT. Raja Grafindo Persada.

Dalimunthe, R. A. (2021). Kedisiplinan Belajar Pesantren. Al-Fikru: Jurnal Ilmiah, 13(2), 112-118. https://doi.org/10.51672/alfikru.v13i2.1 4

Fahmi, F., \& Bitasari, W. (2021). Revitalisasi Implementasi Kurikulum Pendidikan. Al-Fikru: Jurnal Ilmiah, 14(2), 81-91. https://doi.org/10.51672/alfikru.v14i2.3 0

Faizah, S. N. (2017). Hakikat Belajar dan Pembelajaran. At-Thullab: Jurnal Pendidikan Guru Madrasah Ibtidaiyah, 1(2), 175-185.

Hidayat, M. (2017). Pengaruh Kebiasaan Belajar, Lingkungan Belajar, dan Dukungan Orang Tua terhadap prestasi belajar mata pelajaran ekonomi pada siswa kelas IX IPS di Man Bangkalan. Jurnal Ekonomi Pendidikan Dan Kewirausabaan, 3(1), 103-114. http://dx.doi.org/10.26740/jepk.v3n1.p 103-114

Lubis, R. R., Irwanto, I., \& Harahap, M. Y. (2019). Increasing Learning Outcomes and Ability Critical Thinking of Students Through Application Problem Based Learning Strategies. International Journal for Educational and Vocational Studies, 1(6), 524-527.

Manurung, P. (2021). Multimedia Interaktif Sebagai Media Pembelajaran Pada Masa Pandemi Covid 19. Al-Fikru: Jurnal Ilmiah, 14(1), 1-12. https://doi.org/10.51672/alfikru.v14i1.3 3

Ningsih, R., \& Nurrahmah, A. (2016). Pengaruh kemandirian belajar dan perhatian orang tua terhadap prestasi belajar matematika. Formatif: Jurnal Ilmiah Pendidikan MIPA, 6(1), 15-23. http://dx.doi.org/10.30998/formatif.v6i 
1.754

Pane, A., \& Dasopang, M. D. (2017). Belajar dan pembelajaran. Fitrab: Jurnal Kajian Ilmu-Imu Keislaman, 3(2), 333-352. https://doi.org/10.24952/fitrah.v3i2.9 45

Purwanto, D. (2020). Analisis Kebiasan Belajar pada Hasil Belajar Siswa Kelas IV SDN 4 Sempu Tabun Pelajaran 2019/2020. STKIP PGRI Pacitan. https://repository.stkippacitan.ac.id/id /eprint/352/

Purwanto, N. (2014). Psikologi pendidikan. PT. Remaja Rosdakarya.

Rahayu, M. M. (2015). Pengaruh Kebiasaan Belajar terhadap Hasil Belajar Matematika. Journal of Elementary Education, 4(1), 39-45.

Saputra, A., Syahrilfuddin, S., \& Noviana, E. (2016). Hubungan antara Kebiasaan Belajar dengan Hasil Belajar Siswa Kelas V SD Se-kecamatan Tampan. Jurnal Online Mahasiswa Fakultas Keguruan Dan Ilmu Pendidikan Universitas Riau, 3(2), 1-13. jom.unri.ac.id/index.php/JOMFKIP/a rticle/view/12002

Siagian, R. E. F. (2015). Pengaruh Minat dan Kebiasaan Belajar Siswa Terhadap Prestasi Belajar Matematika. Formatif: Jurnal Ilmiah Pendidikan MIP A, 2(2), 3042.

http://dx.doi.org/10.30998/formatif.v $2 \mathrm{i} 2.93$

Siyoto, S., \& Sodik, M. A. (2015). Dasar metodologi penelitian. Literasi Media Publishing.

Syafi'i, A., Marfiyanto, T., \& Rodiyah, S. K. (2018). Studi Tentang Prestasi Belajar Siswa dalam Berbagai Aspek dan Faktor Yang Mempengaruhi. Jurnal Komunikasi Pendidikan, 2(2), 115-123.

Syarifuddin, A. (2011). Penerapan Model Pembelajaran Cooperative Belajar dan faktor-faktor yang mempengaruhinya. Ta'dib: Jurnal Pendidikan Islam, 16(01), 113-136.

https://doi.org/10.19109/td.v16i01.57

Thaib, E. N. (2013). Hubungan Antara Prestasi Belajar dengan Kecerdasan Emosional. Jurnal Ilmiah Didaktika: Media Ilmiah Pendidikan dan Pengajaran, 13(2), 50-70.

http://dx.doi.org/10.22373/jid.v13i2.48 5

Widayanti, F. D. (2013). Pentingnya mengetahui gaya belajar siswa dalam kegiatan pembelajaran di kelas. Erudio Journal of Educational Innovation, 2(1), 4063. http://digilib.uinsby.ac.id/30886/

Wijaya, S. A., \& Saputri, S. D. (2019). Pengaruh Kebiasaan Belajar Terhadap Prestasi Belajar Siswa. Ekuitas: Jurnal Pendidikan Ekonomi, 7(2), 117-121. http://dx.doi.org/10.23887/ekuitas.v7i2 .17917 